\title{
Use of solaria to predict weed density and floristic composition in no-till cropping systems
}

\author{
Pablo Antonio Calviño(1) and Juan José Eyherabide(2)
}

\begin{abstract}
(1)Asociación Argentina de Consorcios Regionales de Experimentación Agrícola, Consorcio Regional de Experimentación Agrícola de Tandil, Bolivar 710, Tandil, 7000, Argentina. E-mail: pcalvino@infovia.com.ar (2)Universidad Nacional de Mar del Plata, Facultad de Ciencias Agrarias, CC 276 Balcarce, 7620, Argentina. E-mail: jeyherabide@balcarce.inta.gov.ar
\end{abstract}

\begin{abstract}
The objective of this work was to evaluate the efficiency of a new method, developed for predicting density and floristic composition of weed communities in field crops. Based on the use of solaria (100 $\mu \mathrm{m}$ transparent plastic tarps lying on the soil) to stimulate weed seedlings emergence, the method was tested in Tandil, Argentina, from 1998 to 2001. The system involved corn and sunflower in commercial no-till system. Major weeds in the experiments included Digitaria sanguinalis, Setaria verticillata and S. viridis, which accounted for $98 \%$ of the weed community in the three years of experiments since 1998. Large numbers of Tagetes minuta, Chenopodium album and Ammi majus were present in 2001. Comparison of weed communities under solaria with communities in field crops indicated that the method is useful for predicting the presence and density of some major weed species, at both high and low densities, of individuals in areas of 10 ha using only five solaria. Low density of weed species makes the method particularly useful to help deciding the time for herbicide applications to avoid soil contamination.
\end{abstract}

Index terms: solarization, weed seedling emergence.

\section{Uso de solaria na predição da densidade de ervas daninhas e da composição florística no sistema de semeadura direta}

\begin{abstract}
Resumo - O objetivo deste trabalho foi avaliar a eficiência de novo método, desenvolvido para predizer a densidade e a composição florística das comunidades de plantas daninhas. O método é baseado no uso de solaria (plástico transparente de $100 \mu \mathrm{m}$ sobre o solo), a fim de estimular o aparecimento de ervas daninhas, e foi testado em Tandil, Argentina, de 1998 a 2001. O sistema envolve milho e girassol, em cultivos comerciais em semeadura direta. As principais espécies experimentadas foram Digitaria sanguinalis, Setaria verticillata e $S$. viridis, que responderam por $98 \%$ da comunidade nos três anos de experiência. Números altos de Tagetes minuta, Chenopodium album e Ammi majus estavam presentes em 2001. A comparação de comunidades de ervas daninhas sob solaria com comunidades fora de solaria indicou que o método é útil para predizer a presença e a densidade de espécies com densidades altas e baixas de indivíduos em áreas de 10 ha com o uso apenas de cinco solaria. Espécies com baixas densidades tornam o método particularmente útil para ajudar a decidir o uso ou não de herbicidas para evitar a contaminação da terra.
\end{abstract}

Termos para indexação: solarização, emergência de ervas daninhas.

\section{Introduction}

No-till sowing has become a common agricultural practice in Argentina during the last decade. In the 2001/ 2002 cropping season, five million ha, equivalent to $30 \%$ of the total area devoted to agricultural production in the country, were cultivated with this technique (Peiretti, 2002). No-till is particularly widespread where double cropping (wheat followed by soybean in the same cropping season) is also used to minimize soil erosion, maintaining soil structure and avoiding organic matter loss.
Some aspects make weed management in no-till different from that used in conventional system. Some examples are: there is no chance to perform inter-row cultivation, when crops are growing; it is impossible to incorporate preplanting herbicides by mechanical means; and the performance of some preemergence herbicides can be affected, because they are retained by crop residues (Locke \& Bryson, 1997). In the southeast of Buenos Aires Province, Argentina, no-till sowing of summer crops, under high volume of residues, reduces the efficacy of preemergence herbicides to control 
Digitaria sanguinalis, Setaria spp., Xanthium spinosum, X. cavanillesii, Tagetes minuta, Ammi majus, Verbesina encelioides, and Ammi visnaga (Eyherabide, 1995, 1996; Bedmar, 1996).

It is useful to know, in advance, the major weed species that will be competing with the crop in the forthcoming season. This would allow alternative means for weed control, such as crop rotation, alternative crop species, and change in planting date, when possible. It would also allow to make decisions on whether preemergence herbicides will be more efficient than postemergence, to minimize weed competition, in order to achieve highest profit and reduce soil contamination.

Annual weeds emerge from soil seed bank and traditional methods to find out existing weed seed species, and their potential to produce seedlings, are expensive and time-consuming (Wiles \& Schweizer, 1999). These methods require many small soil samples, to reach an accurate prediction, and a cumulative soil surface of at least 200 to $300 \mathrm{~cm}^{2}$ would be necessary to capture variations in the seedbank (Forcella et al., 1992; Cardina \& Sparrow, 1996).

Solarization (heating of the soil by a plastic tarp) can be used to obtain soil sterilization, in tropical areas with high solar radiation. This process kills seeds, when soil temperature reaches $70^{\circ} \mathrm{C}$ during seven days or longer (Egley, 1990). Based in the same principle of solar soil heating, a new method of weed seedling prediction has been proposed by Eyherabide et al. (2003), who demonstrated that, in temperate areas of Argentina and USA, temperatures under the tarp are high enough to anticipate weed seeds germination, but not to kill seeds or seedlings. The method was demonstrated to be useful to predict the emergence of Setaria viridis and Chenopodium album, in conventional tillage systems of USA. In Argentina, it was useful for detecting the presence of $D$. sanguinalis in no-till soybean and corn.

Solaria predict either high or low density of weeds, even for cases in which weed control measures would not be necessary, especially for $D$. sanguinalis in notill soybean and corn. The method has also demonstrated its usefulness, when weed counting within the crop are performed near places where solaria had been located.
However, questions about the use of the method to predict weed seedling emergence, for bigger areas and for low number of seeds of broad leaved species, remain (Eyherabide et al., 2003).

The experiment here reported had the objective of evaluating the ability of solaria, located in commercial crops, to predict the different weed species emergence competing with corn and sunflower grown in no-till in the southern Pampas of Argentina.

\section{Material and Methods}

All experiments were carried under field conditions in Tandil ( $\left.37^{\circ} \mathrm{S} 59^{\circ} \mathrm{W}\right)$ in two sites in 1998, 12 in 1999, and four in 2001 (Table 1). Soil in the experimental areas was Typic Argiudoll Balcarce clay loams (Cabria \& Culot, 1994). Topsoil organic matter was $6.7 \%$ and $\mathrm{pH}$ between 5.8 and 6.3 .

All sites had, at least, three years under no-till system and different periods in which weed seed production was avoided by spraying glyphosate in fallows at variable dose. Relevant actions performed before beginning the experiments are listed in Table 1. In each site, within an area of approximately 10 ha, five solaria, $1 \times 1 \mathrm{~m}$ and $100 \mu \mathrm{m}$ thick plastic tarps fixed with wires to the soil (Eyherabide et al., 2003), were installed in plots randomly chosen, between 30 and 45 days before sowing corn or sunflower.

Table 1. Locations description, previous crop, crop to be planted, and months without weed seeds production in the experimental sites.

\begin{tabular}{clllc}
\hline Year & Sites and area (ha) & Previous-crop & Crop to plant & No weed seeds \\
\hline 1998 & EN 7 a (39) & Wheat & Corn & 36 \\
1998 & EN 2 a (33) & Wheat & Corn & 36 \\
1999 & Arroyo 4 (49) & Wheat & Corn & 36 \\
1999 & EN 11 (38) & Wheat & Corn & 36 \\
1999 & EN 16 (61) & Wheat & Corn & 48 \\
1999 & EN 14 (35) & Wheat/soybean & Corn & 36 \\
1999 & Cerro DL 10 (63) & Wheat & Corn & 36 \\
1999 & Cerro DL 9 (68) & Wheat & Sunflower & 48 \\
1999 & San Luis 1a (63) & Wheat & Corn & 9 \\
1999 & San Luis 1b (3) & Wheat & Corn & 36 \\
1999 & San Luis 2a (44) & Wheat & Sunflower & 9 \\
1999 & San Luis 2b (3) & Wheat & Corn & 48 \\
1999 & San José 34a (44) & Wheat & Corn & 9 \\
1999 & San José 34b (3) & Wheat & Corn & 48 \\
2001 & Site 1a (5) & Wheat & Corn & 9 \\
2001 & Site 1b (2) & Wheat & Corn & 48 \\
2001 & Site 2a (5) & Wheat & Sunflower & 9 \\
2001 & Site 2b (2) & Wheat & Sunflower & 60 \\
\hline
\end{tabular}


Thirty days later, solaria were folded back and weeds were counted and removed. Corn and sunflower were sown in all plots and all years from 6 to 20 of October, at 70,000-75,000 and 58,000-65,000 seeds ha-1, respectively, in rows $0.7 \mathrm{~m}$ apart. The disks of the sowing machine only promoted slight soil disturbance in the crop row, at the moment of crop sowing.

No weed control was performed in the experimental areas, between the time of placement of the solaria and counting of weed seedlings, prior to any postemergence herbicide application. In 1998 and 1999, weed seedlings in the crop were counted in five places chosen through a new randomization out of the solaria location, in quadrats of $1 \times 1 \mathrm{~m}$, between 30 and 40 days after sowing date, equivalent to 3-4 leaves of crop growth stage.

In the experiments carried out in 2001, scouting within the crop was performed between 30 and 40 days after planting, similarly to previous experiments, in ten places chosen in each experimental area, in quadrats of 3x1.4 m.

Regression analysis was used to relate densities of dominant weed species under solaria (SWD), with the estimation of in-crop weed density (CWD) recorded before postemergence herbicide application.

\section{Results and Discussion}

Weed species composition in both solaria and untreated crop sections was similar in 1998 and 1999, but different in 2001. Separate analyses were thus performed to account for floristic composition of weed communities.

Digitaria sanguinalis, S. verticillata and S. viridis comprised more than $90 \%$ of weed seedling species, recorded in all experimental sites in 1998 and 1999 in both solaria and untreated crop sections, so they were analyzed as annual grasses. Data of SWD and CWD from fields with different periods, in which weeds had not formed seeds in previous years (Table 1), showed that weed seedling number of both species decreased, depending on the number of years of avoidance of weed seed return to the soil. After four years of avoiding seed set, SWD as well as CWD were reduced practically to zero (Figure 1). This phenomenon is mainly a consequence of the glyphosate application during several years in fallows and of the efficient weed control techniques during crop growth; former researchers have demonstrated that several years of weed control in commercial crops can diminish significantly the size of the soil seed bank (Schweizer \& Zimdahl, 1984; Ball \& Miller, 1990). Weed seed distribution in the soil bank depends on the type of soil previous management (Ball, 1992; Yenish et al., 1992; Clements et al., 1996), while the number of seeds per unit area depends mainly on the efficacy of weed control measures performed in previous years (Ball, 1992; Buhler, 1999; Swanton et al., 2002). Besides, the decline rate of emergence of weeds can be exponential, if they are not allowed to set seeds, as determined by Egley \& Williams (1990).

In experiments performed in 1998 and 1999, a significant association was found between SWD and CWD for grass species (Figure 2). This is especially important, when the number of seedlings is low under solaria conditions, since dots show a higher accordance when the number of seedlings under solaria and within the crop is less than $5 \mathrm{~m}^{-2}$. Dots show less association when the amount of individuals is higher than $5 \mathrm{~m}^{-2}$ and, in consequence, less doubt of applying control measures exists. A similar tendency was found by Eyherabide et al. (2003) for D. sanguinalis.

In 2001, weed communities were more diverse (Table 2). Most important species in 2001 were grasses D. sanguinalis, S. verticillata and S. viridis, as in 1998

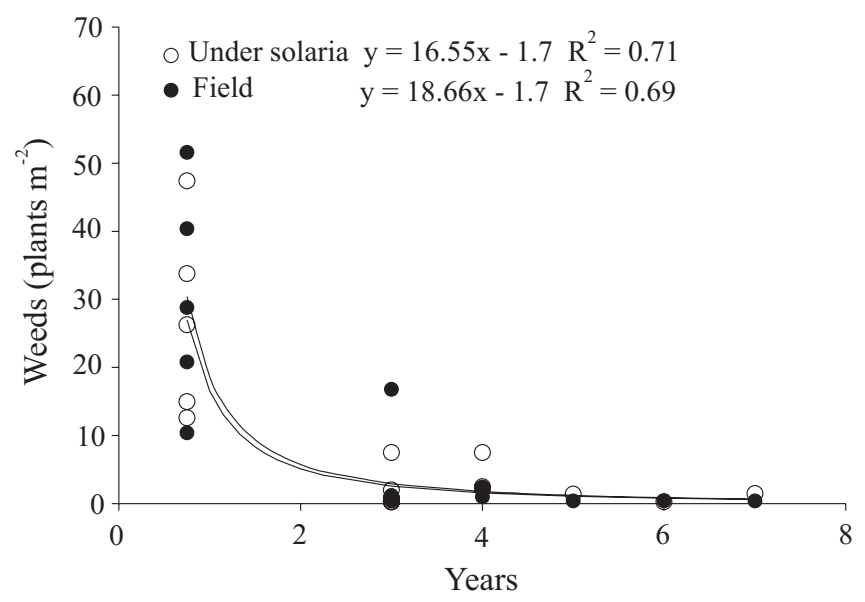

Figure 1. Number of grass seedlings emerging under solaria and in the field, according to the number of years in which weeds were not allowed to yield seeds, in experiments performed in 1998/1999. 
and 1999, however, C. album was present in all sites. The species A. majus was present in three of the four sites, and T. minuta was in three under solaria and in two within the crop. These five species comprised more than $98 \%$ of the total weed community in 2001.

In 2001, a similar relationship was found for grasses, C. album, A. majus and T. minuta (Figure 3). A better association among predicted and observed weeds was found when the number of weed was low (Figure 3). This piece of information confirms those published by Eyherabide et al. (2003), and data shown in Figure 2. All three species are major weeds in summer crops in the southeast of Buenos Aires Province (Bedmar, 1996; Eyherabide, 1996).

These results indicated that the method of solaria is useful for grass seedlings prediction, and more important,

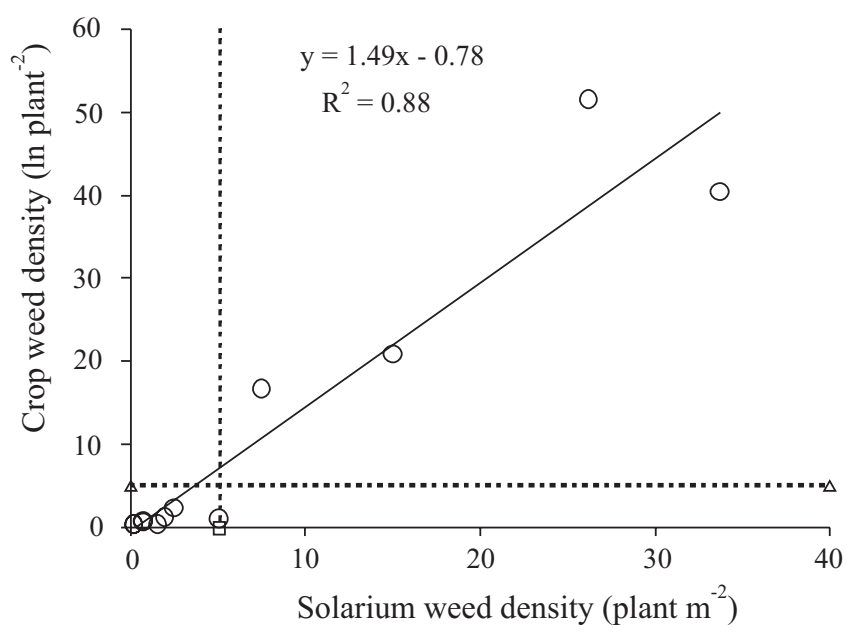

Figure 2. Relationship between grass seedlings under solaria and those appeared within the field, in experiments performed in 1998 and 1999. Each point represents the average of five solaria or ten scouts within the field. Dotted lines represent the number of individuals under solaria or within the crop below which control should not be performed. predicts, in an acceptable way, the presence of major broad leaved weeds in no-till commercial fields, specially when weeds seedlings were present.

It is remarkable to indicate the need of farmers to know in advance the scope of weeds competing with the next crop, mainly the owners of experimental sites, in order to use this technique and make decisions to perform weed control measures.

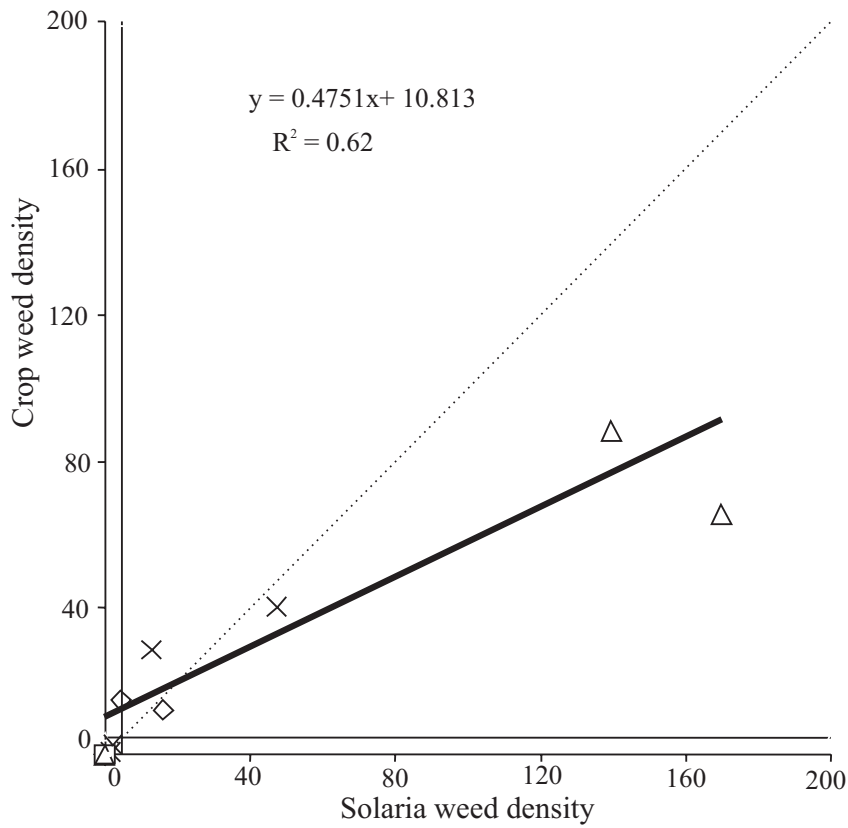

Figure 3. Relationship between grasses $(\times)$, Tagetes minuta $(\diamond)$, Chenopodium album $(\Delta)$, and Ammi majus $(\square)$ seedlings under solaria (solaria weed density) and those appeared within the crop (crop weed density), in the experiment performed in 2001. Each point represents the average of five solaria or ten scouts within the field. Dotted lines denote the areas in which number of individuals, per each species, is less than five, and theoretical line in which $100 \%$ correspondence of SWD and CWD would occur.

Table 2. Mean and standard deviation of number of weed plants (plants $\mathrm{m}^{-2}$ ), in experiment performed in 2001, with solaria (SWD) and planted crops (CWD) under no-till cropping systems.

\begin{tabular}{|c|c|c|c|c|c|c|c|c|c|}
\hline \multirow[t]{2}{*}{ Experimental sites in 2001} & \multirow[t]{2}{*}{ Statistic } & \multicolumn{2}{|c|}{ Grasses $^{(1)}$} & \multicolumn{2}{|c|}{ Tagetes minuta } & \multicolumn{2}{|c|}{ Chenopodium album } & \multicolumn{2}{|c|}{ Ammi majus } \\
\hline & & SWD & CWD & SWD & CWD & SWD & $\overline{C W D}$ & SWD & CWD \\
\hline \multirow[t]{2}{*}{$1 \mathrm{a}$} & Mean & 12.6 & 28.8 & 3.8 & 12.0 & 22.6 & 65.4 & 139.6 & 88.4 \\
\hline & Std. dev. & 18.0 & 36.3 & 28.1 & 13.3 & 22.0 & 91.5 & 219.3 & 157.1 \\
\hline \multirow[t]{2}{*}{$1 b$} & Mean & 2.2 & 2.4 & 0.0 & 0.0 & 0.2 & 0.6 & 1.2 & 0.2 \\
\hline & Std. dev. & 2.4 & 2.3 & 0.0 & 0.0 & 0.4 & 1.3 & 1.3 & 0.4 \\
\hline \multirow[t]{2}{*}{$2 \mathrm{a}$} & Mean & 47.4 & 40.4 & 4.0 & 14.8 & 36.2 & 69.2 & 169.8 & 72.8 \\
\hline & Std. dev. & 78.2 & 49.1 & 2.0 & 14.2 & 57.0 & 128.9 & 228.4 & 97.4 \\
\hline \multirow[t]{2}{*}{$2 b$} & Mean & 1.4 & 0.4 & 0.2 & 0.0 & 0.2 & 0.2 & 0.0 & 0.0 \\
\hline & Std. dev. & 2.6 & 0.5 & 0.4 & 0.0 & 0.4 & 0.4 & 0.0 & 0.0 \\
\hline
\end{tabular}

(1)Includes Digitaria sanguinalis, Setaria verticillata and S. viridis. 
The need to exert weed control and method of control to be performed, based in bioeconomic models, has been investigated and discussed, and significant reduction of herbicide usage has been observed (Buhler et al., 1996; Forcella et al., 1996). However, one of the most important drawbacks for the adoption of the models by farmers is the cost of extracting and analyzing a high number of soil samples, to know the potential of weed seedlings in the crop (Forcella et al., 1992; Wiles \& Schweizer, 1999). This is especially important because small soil samples lead to high coefficient of variation values, with less accuracy in prediction (Forcella et al., 1992). Instead, with the use of solaria, fewer samples are needed, since an area several hundred times bigger than that covered by a single core containing a soil sample is surveyed with each tarp, increasing the possibility to find seeds present in low numbers.

\section{Conclusions}

1. The method to predict weed seedlings in summer crops, based in solaria, shows the ability to predict weed populations for both low and high weed densities.

2. The major summer crop weeds Tagetes minuta, Chenopodium album and Ammi majus are well predicted by solaria.

3. The method can help to decide the need to perform chemical weed control with acceptable accuracy, when weeds are present in low numbers.

\section{References}

BALL, D.A. Weed seed bank response to tillage, herbicides, and crop rotation sequence. Weed Science, v.40, p.654-659, 1992.

BALL, D.A.; MILLER, S.D. Weed seed population response to tillage and herbicide use in three irrigated cropping sequences. Weed Science, v.38, p.511-517, 1990.

BEDMAR, F. Evaluation of pre-emergent herbicides for weed control in zero tillage maize. Annals of Applied Biology, v.128, p.56-57, 1996.

BUHLER, D.D. Weed population responses to weed control practices. I. Seed bank, weed populations, and crop yields. Weed Science, v.47, p.416-422, 1999.

BUHLER, D.D.; KING, R.P.; SWINTON, S.M.; GUNSOLUS, J.L.; FORCELLA, F. Field evaluation of a bioeconomic model for weed management in corn (Zea mays). Weed Science, v.44, p.915-923, 1996.

CABRIA, F.; CULOT, P. Selección y utilización de características edáficas para discriminar series de Argiudoles en el Sudeste Bonaerense. Ciencia del Suelo, v.12, p.41-55, 1994.
CARDINA, J.; SPARROW, D.H. A comparison of methods to predict weed seedling populations from the soil seedbank. Weed Science, v.44, p.46-51, 1996.

CLEMENTS, D.R.; BENOIT, D.L.; MURPHY, S.D.; SWANTON, C.J. Tillage effects on weed seed return and seedbank composition. Weed Science, v.44, p.314-322, 1996.

EGLEY, G.H. High-temperature effects on germination and survival of weed seeds in soil. Weed Science, v.38, p.429-435, 1990.

EGLEY, G.H.; WILLIAMS, R.D. Decline of weed seeds and seedling emergence over five years as affected by soil disturbances. Weed Science, v.38, p.504-510, 1990.

EYHERABIDE, J.J. Evaluation of pre-emergent herbicides applications against Digitaria Sanguinalis in no-tillage soybeans. Annals of Applied Biology, v.126, p.66-67, 1995.

EYHERABIDE, J.J. Evaluation of pre-emergent herbicides for weed control in no-tillage soybeans. Annals of Applied Biology, v.128, p.64-65, 1996.

EYHERABIDE, J.J.; CALVIÑO, P.A.; FORCELLA, F.; CENDOYA, G.; OSKOUI, K.E. Solaria help predict in-crop weed densities. Weed Technology, v.17, p.166-172, 2003.

FORCELLA, F.; KING, R.P.; SWINTON, S.M.; BUHLER, D.D.; GUNSOLUS, J.L. Multy-year validation of a decision aid for integrated weed management in row crops. Weed Science, v.44, p.650-661, 1996.

FORCELLA, F.; WILSON, R.G.; RENNER, K.A.; DEKKER, J.; HARVEY, R.G.; ALM, D.A.; BUHLER, D.D.; CARDINA, J. Weed seedbanks of the United States corn belt: magnitude, variation, emergence and application. Weed Science, v.40, p.636-644, 1992.

LOCKE, M.A.; BRYSON, C.T. Herbicide-soil interactions in reduced tillage and plant residue management systems. Weed Science, v.45, p.307-320, 1997.

PEIRETTI, R. Consideraciones sobre el sistema agrícola argentino. Desafíos y oportunidades frente al escenario actual. In: CONGRESO NACIONAL DE ASOCIACIÓN ARGENTINA DE PRODUCTORES EN SIEMBRA DIRECTA, 10., 2002, Rosario, Santa Fe, Argentina. Anais. Rosario, Santa Fe, Argentina: Aapresid, 2002. p.41-71.

SCHWEIZER, E.E.; ZIMDAHL, R.L. Weed seed decline in irrigated soil after rotation of crops and herbicides. Weed Science, v.32, p.84-89, 1984.

SWANTON, C.J.; SHRESTHA, A.; CLEMENTS, D.R.; BOOTH, B.D.; CHANDLER, K. Evaluation of alternative weed management systems in a modified no-tillage corn-soybean-winter wheat rotation: weed densities, crop yield, and economics. Weed Science, v.50, p.504-511, 2002.

WILES, L.J.; SCHWEIZER, E.E. The cost of counting and identifying weed seeds and seedlings. Weed Science, v.47, p.667-673, 1999.

YENISH, J.P.; DOLL, J.D.; BUHLER, D.D. Effects of tillage on vertical distribution and viability of weed seed in soil. Weed Science, v.40, p.429-433, 1992. 